the first to observe the refractory phase of the heart in 1874-Stirling is remembered chiefly as an interpreter of the work of others, as an organizer and as a lecturer. The first edition of his translation of Leonard Landois's "Lehrbuch der Physiologie des Menschen" (1884) met a real need. His other books included "Outlines of Physiological Chemistry" (1881), "Outlines of Practical Physiology" (1888), "Outlines of Practical Histology" (1890) and "Some Apostles of Physiology" (1902). More than six feet tall and always immaculately dressed, William Stirling was an impressive personality and a fine speaker, who prepared his lectures with infinite care and illustrated them with a wealth of models and historical allusions. He retired in 1919 and died on October 1, 1932.

\section{Committee on Growth and Form: Research in Anthropometry}

THE Medical Research Council has appointed a Committee on Growth and Form, under the chairmanship of Prof. P. B. Medawar, Mason professor of zoology in the University of Birmingham, with the following terms of reference: "To advise and assist the Medical Research Council $(a)$ in promoting research on the growth and form of the human body with particular regard to the provision of basic scientific data, including the elucidation of factors affecting the rate of growth of the whole body and of its parts and the establishment of norms of stature and weight for different ages and different sections of the population; and $(b)$ in facilitating the application of such data to various practical problems, including such as arise within the field of clinical medicine". One of the Committee's first tasks is to make a review of work in the field of anthropometry. The Committee would accordingly be glad to have information about current or completed anthropometric surveys, including unpublished records, so as to avoid any unnecessary repetition of work and to ensure, if possible, that use is made of existing material. It is believed that there are in existence records of height, weight, and other body measurements, which, if analysed, could form the basis for research into growth and development. Serial records of the growth of the same children from year to year, as well as measurements which have been recorded over a long period of time, would be particularly valuable. The secretary of the Committee, to whom all communications should be addressed, is $\mathrm{Mr}$. E. M. B. Clements, M.R.C. Committee on Growth and Form, Medical School, Hospitals Centre, Birmingham, 15.

\section{Chemical Investigations on Cores collected from the Deep-sea Floor}

A FUND has been established, with generous donations from Swedish commercial sources, to enable chemical investigations to be undertaken in the Department of Mineralogy of the British Museum, under the direction of Dr. J. D. H. Wiseman, on one or two of the long cores from the sea floor collected by the Swedish Deep-Sea Expedition in 1947-48, led by Prof. Hans Pettersson. The fund is administered by an Anglo-Swedish Committee consisting of Prof. Hans Pettersson (chairman), director of the Göteborg Oceanographical Institute; Dr. G. Ahlström, director of the Swedish Institute, London; Dr. L. H. N. Cooper, Marine Biological Association of Great Britain, Plymouth; Dr. W. Campbell Smith, Dr. M. H. Hey and Dr. J. D. H. Wiseman (secretary), all of the Department of Mineralogy, British Museum (Natural History). The Committee has secured the services of Mrs. Anne Foster, who has previously carried out chemical research under Prof. I. S. Theobald, of the Imperial College of Science and Technology, London. In order to achieve a better understanding of geochemical cycles, it is necessary to have more information about the com. position of the surface layer of the deep-sea floor, which covers approximately two-thirds of the earth's surface, as well as of the changes which take place with increasing depth below the surface layer. It would seem that in favourable places deep-sea cores will reveal a continuous record of past changes in the world's history. For example, Dr. Wiseman has recently shown that past climatic changes may be revealed and dated through investigations on deepsea cores (The Times, Sept. 22, 1950). In view of the generous initial donations from Sweden-an excellent example of international scientific co-operation-and of the importance of this investigation, which leads into many unexplored fields, it is hoped that substantial additions will be made to this fund from British sources.

\section{Possible Mechanism of Virus Reproduction}

A USEFUT review of the mechanism of virus reproduction in bacteriophage, by S. E. Luria (Science, 111, No. 2889; May 12, 1950), makes use of the hypothesis that the virus introduces a completely predominant organizer of specificity into the bacterial cell, in what could be called parasitism at the genetic level. Infection disrupts the genetic organization of the host and changes the organization of the infecting virus, to form a new unit, the virus. infected cell. This contains the existing enzymatic machinery of the host and, "superimposed upon it, a genetic pattern derived from the virus and directing the synthesis of virus material from nonspecific building blocks". The author indicates certain parallels of this idea in animal viruses, and it might be added that the hypothesis is not at variance with what is known about certain plant viruses.

\section{Research in the Small Firm}

$I_{N}$ an address to the Autumn Management Conference of the British Institute of Management which was held at Harrogate in October 1950, Mr. W. E. Benton discussed the functions of the research department in a small firm. In a large organization the research department may be charged with the development of new products, the control and improvement of production processes, the testing of materials, components and complete production units, and the investigation of faults in products. In a small firm it is impossible to ignore the pressing claims of production problems, and the research department is often expected to investigate every problem of a technical nature which arises in the conduct of the firm's business. When the firm is particularly busy, production problems multiply, and the end of a boom period may find the development of new products very far behind the original programme. The research scientist himself should not only be well qualified academically but should have had some training in the use of tools and have appreciation of the qualities of materials and finishes; some artistic ability or an appreciation of good design is equally desirable. Mr. Benton also describes the way in which he thinks the research department in a small firm should be organized. 